\title{
Features of karyotyping variabilityof daughters of bulls-embrio-grafts
}

\author{
V.Dzitsiuk, \\ doctor of agricultural sciences \\ M. Peredrii
}

The purpose. To investigate cytogenetic characteristicsof cows which descend from the bulls gained by themethod of embrio-transplantation and cows-descendantsof bulls, born after artificial fertilization. Methods.Cultivation of lymphocytes, preparation of cytogeneticspecimens, classification and account of aberrationsof chromosomes realized under practical standards.Results. Abnormalities of karyotype of genome type(aneuploidy and polyploidy) and structural aberrationsof chromosomes (fragments, breakages, shortages andassociations of chromosomes) are determined by resultsof analysis. General frequency of karyotypic infringementsat cows-daughters of bulls from embryo-transplantationwas higher for $10 \%$ in comparison with indexat cows-daughters of bulls from artificial fertilization.At cows that had even one deadborn or spontaneousabortions, frequency of chromosomal infringements wasconsiderably higher, than at animals without coarse reproductiveinfringements. Conclusions. For preventingaccumulation of genetic imperfections in herds of cattleit is necessary to spend regular cytogenetic monitoringof animals.

Key words: cattle, transplantation of embryos, karyotype, aberrations of chromosomes.

A progressive trend of an accelerated reproduction of cattle in a form of embryo transplantation reveals an ability to intensively use the genetic potential of high-performance cows, to get twins through a transplantation of two embryos to one recipient, to preserve the gene pool of local and endangered species, to create a bank of embryos from outstanding animals using deep freezing method, to simplify the transportation of the genetic material to various regions of the world.

The idea of embryo transplantation is based on the ability of the pre-implant embryo to retain the viability outside mother organism for some time, as well as on the phenomenon of tolerance of recipient's organism to a transplanted embryo.

Numerous facts proving the absence of the growth and performance differences between transplant animals and their peers received by artificial insemination show the effectiveness and capacity of this biotechnological method. Despite the obvious fact that the animals received by transplantation do live and produce offspring, it is not convincingly proved that their physiology, metabolism and gene expression has no defects or at least any features. The literature contains only isolated reports of possible biological risks of this technology, including the ones about the accumulation of genetic cargo in the offspring of animals derived from the embryo transplantation method, and about negative consequences of biotechnical manipulation of embryos [1, 2, 3].

Obviously, the manipulations provided alongside the transplantation must affect the viability and development of transplanted embryos, in particular, hormonal stimulation of donor cows, in other words, the repeated injection of prostaglandin and follicle-stimulating hormone cause irreversible changes for the donors $[4,5]$.

The research works by F. Cherneva [6] prove the fact that the karyotypes of embryo donors of blackmotley breed have trans-chromosomal associations after follicle-stimulating hormone (FSH) is injected. These associations are the result of artificial changes in hormonal status.

The number of stillbirths and animals with various pathologies increases among twins obtained by transplantation. And the risk of their death is higher as well, as compared to the naturally born offspring. In literature there are no reports on any research on the impact of leaching procedures, embryos evaluation of integrity of karyotype of transplant animals and their descendants at least in the first generation. 
T. Glazko etc. [5] reported that cows with cytogenetic abnormalities have a higher level of reaction to the gonadotropins injection, resulting in increasing the number of embryos with cytogenetic disturbances, which in case of successful transplantation would lead to the accumulation of genetic load for the subsequent generations. This means that the offspring of bull transplants can have adverse chromosomal aberrations and karyotype instability, which could affect their viability and productivity. Thus, the problem of interference effects is studied not well enough. There are no scientific data on the biological integrity of the offspring obtained through embryo transplantation, particularly the daughters of bull-transplants.

The aim of our study is to compare the karyotype variability, the variability of productive traits and reproductive capacity indicators of the daughters of bulls obtained by embryo transplantation method and cows-daughters from bulls born from artificial insemination.

Materials and Methods. As the material for the study we took the results of individual assessment of animals of Ukrainian red-spotted milk breed from State Enterprise Research Farm «Khrystynivka» by the materials of zootechnical accounting and experimental cytogenetic data. The 'Intesel Orsek' Dairy Management System software was used for the analysis.

The cytogenetic research was held in the laboratory of Institute of Animal Breeding and Genetics nd.a. M.V. Zubets of NAAS. The groups were formed of cows derived from embryo transplant bulls and bulls from artificial insemination. The cows after $1-2$ lactations were selected for studies.

For the cytogenetic studies the samples of blood from the tail vein were taken using sterile syringes with heparin solution. Short-term culture was prepared by a conventional method [8]. The cultivation of cells had been performed for 72 hours in an incubator at $27^{\circ} \mathrm{C}$. Then the suspension had been centrifuged (1000 $\mathrm{rev} / \mathrm{min}, 10 \mathrm{~min})$, incubated in hypotonic solution of $\mathrm{KCL}(0.54 \%)$ for 50 minutes, fixated using a mixture of ethanol with glacial acetic acid (the ratio of $3: 1$ ) in the following order: the retainer was layered on the cell suspension that was exempt from hypotonic solution. Then the suspension had been held for 90 minutes at $+4^{\circ} \mathrm{C}$. After that the suspension had been centrifuged at $1000 \mathrm{rev} / \mathrm{min}$ for 7 minutes, the supernatant was taken out, the retainer had been added to the suspension and it all has been centrifuged again under the same conditions. After the supernatant was taken out once more and the needed amount of fresh retainer was added, the suspension was tapped onto clean chilled sample glasses. The samples were stained using Giemza dye (Giemza Merk).

The cytogenetic indicators such as: the proportion of aneuploid and polyploid cells, the frequency of cells with structural chromosomal aberrations (chromosomal breaks, fragments of chromosomes, asynchronous cleavage of centromeric regions of chromosomes) were included into the analysis of metaphase cells.

In order to analyze the frequency of micronuclei in erythrocytes, the drop of peripheral blood was diluted with saline (1:1) and the smears were prepared. The calculation of erythrocytes of micronuclei was performed after staining with Giemza dye. The 500 cells were analyzed for each animal.

The biometric processing of the results of the research was carried out using the methods of variation statistics according to N. Plokhynskyi [9], G. Lakyn [10] using standard statistical software package.

Results of Research. The analysis based on zootechnical calculation showed that the first lactation of the daughters of embryo transplanted bulls gave the $146 \mathrm{~kg}$ higher yield compared to the yield of the daughters of bulls born ny a traditional method of artificial insemination (Table 1). Other researchers, as well, cite the similar data on the higher performance of cows-daughters of the bulls-transplants compared to the daughters of non-transplanted bulls.

A better reproductive qualities were noted after the cows whose parents were obtained by artificial insemination. In a group of cows, the descendants of transplanted bulls, there were $13(38,2 \%)$ cases of stillbirth and spontaneous abortions, while the value was only $4(1 \%)$ among the peer daughters of the traditionally received bulls. An average service-period value of the first group of cows was 164.8 days, which is 4 days less. Alongside that, the age of the first insemination is almost 5 months ( 151.9 days) higher.

The two groups of cows were formed for the cytogenetic study based on zootechnical accounting materials. The cows were grouped depending on the method of their parent bulls birth, either it was a method of embryo transplantation or an artificial insemination.

Many authors believe that cytogenetic monitoring is based on karyotype norm and any deviation from the norm should be regarded as a genetic risk [13]. In order to evaluate the karyotype variability we developed the algorithm of generalized cytogenetic indicator called "genetic risk". The indicator is based on primary 
data on the frequency of aneuploid, polyploid cells and cells with chromosomal aberrations and associations. As a result of calculation of genetic risk, the cows-daughters originating both from bulls born by transplanting and artificial insemination were formed into three groups. The first group was for low risk level (L); the second one grouped the cows with moderate genetic risk (M); and the third group was for high level of genetic risk $(\mathrm{H})$.

As it can be seen from the Table 2, the majority of cows are concentrated in a moderate genetic risk. At the same time, the cows whose parent bulls were obtained by embryo transplantation can be found in the group of high genetic risk more often than the daughters of traditionally received bulls.

In order to investigate intergroup differences in cytogenetic characteristics, the researched groups (daughters of embryo transplanted bulls and daughters of bulls received by artificial insemination) were divided into three sub-groups each depending on the status of their reproductive system. The I group contained the animals with disordered reproductive ability, cases of stillbirth and spontaneous abortions, the II group had the cows with service-period of not less than 150 days after the first lactation, the III group had the cows with service-period was 51 to 90 days after the first lactation (Table 3 ).

As the result of analysis of the chromosomes samples it was stated that cows among all groups have abnormalities of karyotype of the genome type as well as structural chromosomal aberrations. The cells with aneuploidy dominated in the genome type aberrations, at the same time there was a less amount of cells with polyploidy. The fragments, gaps, lacks and associations of chromosomes were detected among mutations of chromosomes.

The overall frequency of karyotype disorders was about $10 \%$ higher for the cows-daughters of embryo transplanted bulls as compared to the same indicator for the cows-daughters of the bulls from artificial insemination. The frequency of chromosomal abnormalities was significantly higher for the cows who had at least one case of stillbirth or spontaneous abortions (Group I) as compared to the animals without major reproductive disorders (Groups II and III).

Aneuploidy is represented mainly by hypoploid cells, which during the analysis revealed the significant difference between the groups of animals with various reproductive ability applicable both to cows-daughters of transplant bulls and cows-daughters of bulls of artificial insemination.

Polyploidy is a phenomenon of a fold increase of haploid number of chromosomes in the nucleus. It is found in the studied animals in a mosaicism form, ie polyploids are present only in the part of researched metaphases. Their ratio is also greater in animals with disordered reproductive ability.

The level of structural aberrations in animals of the I and II groups formed of the cows-daughters of bulls born by embryo transplantation as well as cows daughters of bulls received by artificial insemination is higher than in the animals with normal reproductive ability (the III group).

Genetic damages are the result of chromosomal aberrations and lead to the formation of micronuclei, which in turn serve as an indicator for various types of disorders [14]. With the help of micronucleus test it is possible to study a mutagenic sensitivity of living animals. The presence of erythrocytes with micronuclei tells about induction of chromosomal abnormalities and/or miotic apparatus disorders in the studied animals.

Our analysis of the frequency of erythrocytes with micronuclei in peripheral blood of the cows whose parents were received using various biotechnological methods revealed no significant differences and found no excess of spontaneous mutagenesis. According to N. Ilyinskikh [15], the spontaneous level of erythrocytes with micronuclei is ranked about $0.3 \%$ for mammals. The received results showed no mutagenic factors in the region of animal population breeding.

\section{Conclusions}

According to the research we can conclude that for the offspring of bulls received by embryo transplantation we can observe a higher level of karyotype volatility. However, the difference is smaller than between the groups of cows with various reproductive ability. It means that the systematic cytogenetic control has to be maintained in order to prevent the accumulation of genetic defects in cattle herds during the application of biotechnological techniques and purposeful work on reproduction. The specific column needs to be implemented into the breeding card of the animal, where its cytogenetic integrity must be described. 


\section{Bibliography}

1. Бакай Ф.Р. Цитогенетический мониторинг коров-доноров эмбрионов/Ф.Р. Бакай, М.Д. Камачо Чаваррия,Д.М. Старостин//Современные проблемыв зоотехнии: сб. научн. тр. - Ч. 1/Моск. гос. акад.вет. мед. и биотехнол. - М., 2001. - С. $20-22$.

2. Bovine embryo technologies/C. Galli, R. Duchi,G. Crotti et al.//Theriogenology. - 2003. - 59. -P. $599-616$.

3. Hasler J.F. The current status and future ofcommercialembryo transfer in cattle/J.F. Hasler//AnimReprod Sci. - 2003. - 79. - P. $245-264$.

4. Глазко Т.Т. Геномная нестабильность и контроль коров доноров эмбрионов/ Т.Т. Глазко,Г.Ю. Косовский,В.И. Глазко/ААспекты репродуктивной биотехнологии. - Вып. 1. - М.: Изд-во ООО«ПРИЯТНАЯ КОМПАНИЯ», 2012. - С. 136 - 143.

5. Взаимосвязь геномной нестабильности и эмбриопродуктивности у коров-доноров эмбрионов/Т.Т. Глазко, Г.Ю. Косовский, Д.В. Попов, А.В. Бригида//Ветеринария Кубани. — 2015. — № 6. - C. $9-11$.

6. Чернева Ф.Р. Ассоциативная способность хромосом у коров-доноров эмбрионов/Ф.Р. Чернева//Актуальн. вопр. селекц.-племен. работы в животноводстве. - М., 1989. - С. 20 - 22.

7. Маменко О.М. Ризики негативного впливу індустріальних технологій тваринництва на благополуччя тварин (ретроспектива і...?)/О.М. Маменко//Проблеми зооінженерії та ветеринарної медицини:зб. наук. пр. - Вип. 31, Ч. 1/Харк. держ. зоовет.акад. - Х., 2015. - С. 308 - 318.

8. Chromosome preparations of leucocytesculturedhuman peripheral blood/P. S Moorhead,P.C. Nowell, W.J. Mellman et al.//Exp. Cell Res. —1960. — № 20. — P. 613-616.

9. Плохинский Н.А. Руководство по биометриидля зоотехников/Н.А. Плохинский. - М.: Колос. 1969. - $256 \mathrm{c}$.

10. Лакин Г.Ф. Биометрия: учеб. пособие для биол.спец. вузов. - 4-е изд., перераб. и доп./Г.Ф. Лакин.— М.: Высш. шк., 1990. - 352 с.

11. Бакай А.В. Кариотипическая нестабильность у коров в норме и с нарушениями репродуктивных функций при различных вариантахподбора/А.В. Бакай, Ф.Р. Бакай, А.И. Бакай//Сб.науч. трудов БСХА. Актуальные проблемы интенсивного развития животноводства. - 2014.Вып. 17. - С. 3 - 12.

12. Водунон А.С. Цитогенетические измененияв эритроцитах больных атопической бронхиальнойастмой/А.С. Водунон, Н.А. Пономарева, З.И. Абрамова//Ученые записки Казанского гос. ун-та. -2008. - Т. 150. - С. $101-105$.

13. Ильинских Н.Н. Использование микроядерноготеста в скрининге и мониторинге мутагенов/Н.Н. Ильинских, И.Н. Ильинских, В.Н. Некрасов//Цитология и генетика. - 1988. - Т. 22, № 1. - С. 67 - 72. 